\title{
Sediment records of the metal pollution at Chihu Lake near a copper mine at the middle Yangtze River in China
}

\author{
Shuchun YAO, ${ }^{*}$ Bin XUE \\ State Key Lab of Lake Science and Environment, Nanjing Institute of Geography and Limnology, Chinese Academy of Sciences, \\ Nanjing, 210008, China \\ *Corresponding author: shchyao@niglas.ac.cn
}

\begin{abstract}
Two short sedimentary cores were collected in 2012 from Chihu Lake in the middle Yangtze River Basin using a gravity corer. Heavy metals, including $\mathrm{Pb}, \mathrm{Cu}, \mathrm{Zn}, \mathrm{Cd}$, Cr, Co, Ni and Mn, and major elements, including $\mathrm{Al}, \mathrm{Fe}, \mathrm{K}, \mathrm{Mg}$ and Ti, were measured. Radionuclides, including ${ }^{210} \mathrm{~Pb}$ and ${ }^{137} \mathrm{Cs}$, were analyzed to date the sediments. The Mn enrichment in the sediments of the two cores did not significantly influence the distribution of the heavy metals. The Pb, Cu, $\mathrm{Zn}, \mathrm{Cd}$, Co and Ni contents have increased over the past 30 to 40 years. The decrease in the ${ }^{206} \mathrm{~Pb}{ }^{207} \mathrm{~Pb}$ ratios toward the surface also indicated increasing mining sources of Pb loading to the lake sediments. The maximum concentration of $\mathrm{Cu}, \mathrm{Zn}$ and $\mathrm{Cd}$ recorded in the 1990s was 2047, 1343 and $60.9 \mathrm{mg} \mathrm{kg}^{-1}$ dry mass, respectively, and the maximum enrichment factors of $\mathrm{Cu}, \mathrm{Zn}$ and $\mathrm{Cd}$ were 62, 16 and 206, respectively. The heavy metal enrichment at Chihu sediment was high overall because of the mining waste discharge.
\end{abstract}

Key words: Yangtze River; Chihu Lake; sediment; copper mining.

Received: April 2015. Accepted: September 2015.

\section{INTRODUCTION}

Heavy metals in the environment are not only from natural sources, such as erosion and weathering process, but also from anthropogenic emissions, of which the most important have been the human activities of mining and smelting (Nriagu, 1998; Boyle et al., 1999; Pacyna and Pacyna, 2001; Audry et al., 2004; Couillard et al., 2008; Balogh et al., 2009; Wu et al., 2010). Heavy metals can be released into the water environment from mining tailings or transported with metal-rich dust during mining activities (Ek and Renberg, 2001; Salonen et al., 2006; Laperriere et al., 2008; Grayson and Plater, 2009; Ostrofsky and Schworm, 2011). For example, heavy metals can be released into the atmosphere during the refining process due to high temperature smelting (Boyle et al., 1999; Ek and Renberg, 2001). Acid mining drainage (AMD) is formed in mining exploitation and the associated production activities. The AMD effect on the environment, often the aquatic environment, can be easily shown at locations in which heavy metals pose a serious threat to organisms in the receiving water (Michelutti et al., 2001; Ostrofsky and Schworm, 2011). Many heavy metals are toxic to the biota when the concentration exceeds a specific level (Arnason and Fletcher, 2003; Salonen et al., 2006). The toxicity of heavy metals is due to their ability to form stable complexes, which may be with the active site of the denatured protein conformation or the substitution for the activity of a metal cofactor.
The construction of the Wushan Copper Mine began in the 1960s (Wu, 1987b), and the goal was to develop the largest copper mine in Jiangxi, China. The copper remains active today. During the same period of mine construction and exploitation, the population of the mine company grew from 175 in 1966 to 4,077 in 1992 (Li, 1999). Chihu Lake is located to the northeast of the Wushan Copper Mine, and the lake shoreline is partly connected to the mine tailing. Prior to 1989, there was no sewage process system. The waste water from the spoil and the mine waste was discharged into Chihu Lake through surface or underground runoff without treatment (Zhao, 1994). The Chihu Lake water quality has been severely affected by the mine drainage ( $\mathrm{Li}, 1999)$. The waste water loading to Chihu Lake was up to 3.8 million tons, and the $\mathrm{Cu}$ loading was 30 tons in 1989 , resulting in a $\mathrm{Cu}$ concentration up to $200 \mathrm{mg} \mathrm{L}^{-1}$ in the lake water (Compilation Committee of Chorography of Science and Technology of Wushan Copper, 1994). In 1989, two sewage treatment plants were installed (Compilation Committee of Chorography of Science and Technology of Wushan Copper, 1994). Improved rock processing and the implementation of waste water treatment can lead to a reduction in the heavy metal loading to Chihu Lake, but the risk of the mining activities on Chihu Lake remains. According to a simple surface sediment survey conducted by the Nanjing Institute of Geography and Limnology of the Chinese Academy of Sciences in 2007, the $\mathrm{Cu}$ content ranged from $36.3-382.3 \mathrm{mg} \mathrm{kg}^{-1}$, and the $\mathrm{Cd}$ content ranged from $0.292-10.35 \mathrm{mg} \mathrm{kg}^{-1}$ dry mass. 
Paleolimnology offers a unique historical perspective for the study of the effects of the Wushan Copper Mine activities on Chihu Lake and the pre-disturbance environmental conditions of the lake. An analysis of the trace metals in the lake sediment cores with the chronology can provide valuable insights into the historical metal inputs (Boyle et al., 1999; Rose et al., 2004; Yang and Rose, 2005; Couillard et al., 2008). Heavy metals in the Chihu Lake sediments include not only the anthropogenic source but also the metal from the natural input of the catchment. Geochemical methodologies use highly conserved elements, such as aluminum, iron, lithium and rubidium, to detect and quantify the anthropogenic metals input (Franco-Uria et al., 2009; Yao et al., 2009), assuming that these elements are not influenced by human activity and can reflect catchment input. In addition, the use of stable $\mathrm{Pb}$ isotopes can enhance our understanding about the sources of the $\mathrm{Pb}$ in the input, and this analytical tool has been widely used in different ecosystems, including lake sediments(Farmer et al., 1997; Marcantonio et al., 2002; Cheng and $\mathrm{Hu}, 2010)$.

Mining activity is as a point source pollution, and its effect may primarily be limited to the surrounding environment. In this study, we analyzed two sediment cores from Chihu Lake, examining the changes in the heavy metals over time and evaluating the anthropogenic and natural heavy metal inputs on the whole Lake Chihu ecosystem.

\section{METHODS}

\section{Study site}

\section{Chihu Lake}

Chihu Lake, lying on the southern bank of the Yangtze River (Fig. 1), is situated in the administrative region of Ruichang County and Jiujiang County. Chihu Lake had an area of $100.4 \mathrm{~km}^{2}$, but the reclamation during the 1950s-1970s (Compilation Committee of Chorography of Ruichang County, 1990) and the project from 2011-2013 reduced the lake to $30.4 \mathrm{~km}^{2}$ (Fig. 1). The lake is shallow with a mean depth of $2.8 \mathrm{~m}$ and max depth of $3.5 \mathrm{~m}$. The catchment area is $360.0 \mathrm{~km}^{2}$ (Wang and Dou, 1998). Chihu Lake is controlled by a subtropical monsoon climate with an average annual temperature of $16.5^{\circ} \mathrm{C}, 1394$ $\mathrm{mm}$ of annual precipitation and 260 frost-free days in each year (Wang and Dou, 1998).

Nanyang River, originating from the northwestern hillocks, is the most important inlet river, with a length of $30 \mathrm{~km}$. In the 1970s, the river turned into two adjacent rivers for flood control during the summer. In 1954, a dam was installed at Pengjiawan (PJW) (Compilation Committee of Chorography of Ruichang County, 1990) (Fig. 1). Since then, Chihu Lake has become a reservoir-type lake under artificial control. A significant amount of materials from the Yangtze River entered the lake during the summer when flooding occurred and was deposited in the lake before the establishment of the dam. The water level averaged $14.60 \mathrm{~m}$ asl, with a maximum of $17.00 \mathrm{~m}$ in July 1983 and a minimum of $12.49 \mathrm{~m}$ in July 1968 (Wang and Dou, 1998).

The $\mathrm{pH}$ of the Chihu Lake water is 8.0-8.7. The $\mathrm{Ca}^{2+}$, $\mathrm{Mg}^{2+}, \mathrm{Na}^{+}$and $\mathrm{K}^{+}$contents are 37.9 (27.2-48.7) $\mathrm{mg} \mathrm{L}^{-1}$, 7.63 (6.08-9.73) $\mathrm{mg} \mathrm{L}^{-1}, 4.53$ (0.97-3.57) $\mathrm{mg} \mathrm{L}^{-1}$ and 2.25 (3.21-6.40) $\mathrm{mg} \mathrm{L}^{-1}$, respectively. The TN and TP values are $0.72(0.23-3.6)$ and $0.040(0.025-0.070) \mathrm{mg} \mathrm{L}^{-1}$, respectively. Macrophytes are abundant in Chihu Lake. According to an investigation in 1964, the biomass of the macrophytes in the entire lake averaged $2180 \mathrm{~kg}$ per acre (Wu, 1987a). A survey conducted in 1985 revealed that the lake was dominated by Potamogeton malaianus Miq., Vallisneria spiralis L. and Hydrilla verticillata Royle (Wu, 1987a).

\section{Copper mine}

The Wushan Copper Mine contains two ore belts, the Wushan south ore belt and the Wushan north ore belt. The south ore belt contains skarn and porphyry $\mathrm{Cu}$ orebodies, which occur at the contact zone of the granodiorite porphyry. The north ore belt contains stratiform $\mathrm{Cu}$ ore bodies at the lithological boundary between the basal siliciclastic rocks and the overlying carbonates of the Middle Carboniferous Huanglong Formation or in fracture zones within the Huanglong Formation carbonates. The mine contains $1.04-1.17 \% \mathrm{Cu}$ and a smaller amount of Au and Ag (Huang et al., 1990).

Mine exploration in Wushan began in 1959 and continued until 1965. The Wushan Copper Mine construction was between 1966 and 1985(Compilation Committee of Chorography of Science and Technology of Wushan Copper, 1994). In 1970, a contemporary extraction plant was constructed, and 649.4 tons of copper was extracted until 1971(Compilation Committee of Chorography of Science and Technology of Wushan Copper, 1994). From 1977$1983,300,855$ tons of rock was processed in the new extraction plant, averaging approximately 220 tons per day. From 1986-1990, the extraction plant was reconstructed, and approximately 800 tons of rock could be processed per day (Compilation Committee of Chorography of Science and Technology of Wushan Copper, 1994). During the 9th Five-Year (1996-2000), the rock processing capacity at the extraction plant elevated from approximately 1100 tons to 2500 tons per day (Wu et al., 2001). The ore process in 2009 was as high as 5000 tons per day.

A tailing reservoir near the Chihu Lake was established in 1970 . The storage capacity of the tailing reservoir is $460,000 \mathrm{~m}^{3}$. Up to $1990,845,500$ tons of waste rock was deposited in the tailing reservoir. Waste rock deposited before 1992 in the tailing reservoir contains $0.538 \% \mathrm{Cu}$, whereas waste rock deposited after 1992 contained $0.3 \% \mathrm{Cu}$ (Wang, 1997). Large amounts of spoil 
were deposited in the land area of the mine region. An analysis in 1977 revealed that the $\mathrm{Cu}$ concentration in the leaching water from these spoils was as high as $4750 \mathrm{mg}$ $\mathrm{L}^{-1}$ during raining days (Anomournas, 1977). The mine is located on the western shore of Chihu Lake (Fig. 1) and is one of the primary environmental factors affecting the lake water quality in addition to non-point-source loading from land uses in the lake catchment area.

\section{Sampling and laboratory analysis}

Two short sedimentary cores, $\mathrm{CH} 1$ and $\mathrm{CH} 2$, were obtained in 2012 from the eastern and western parts of Chihu

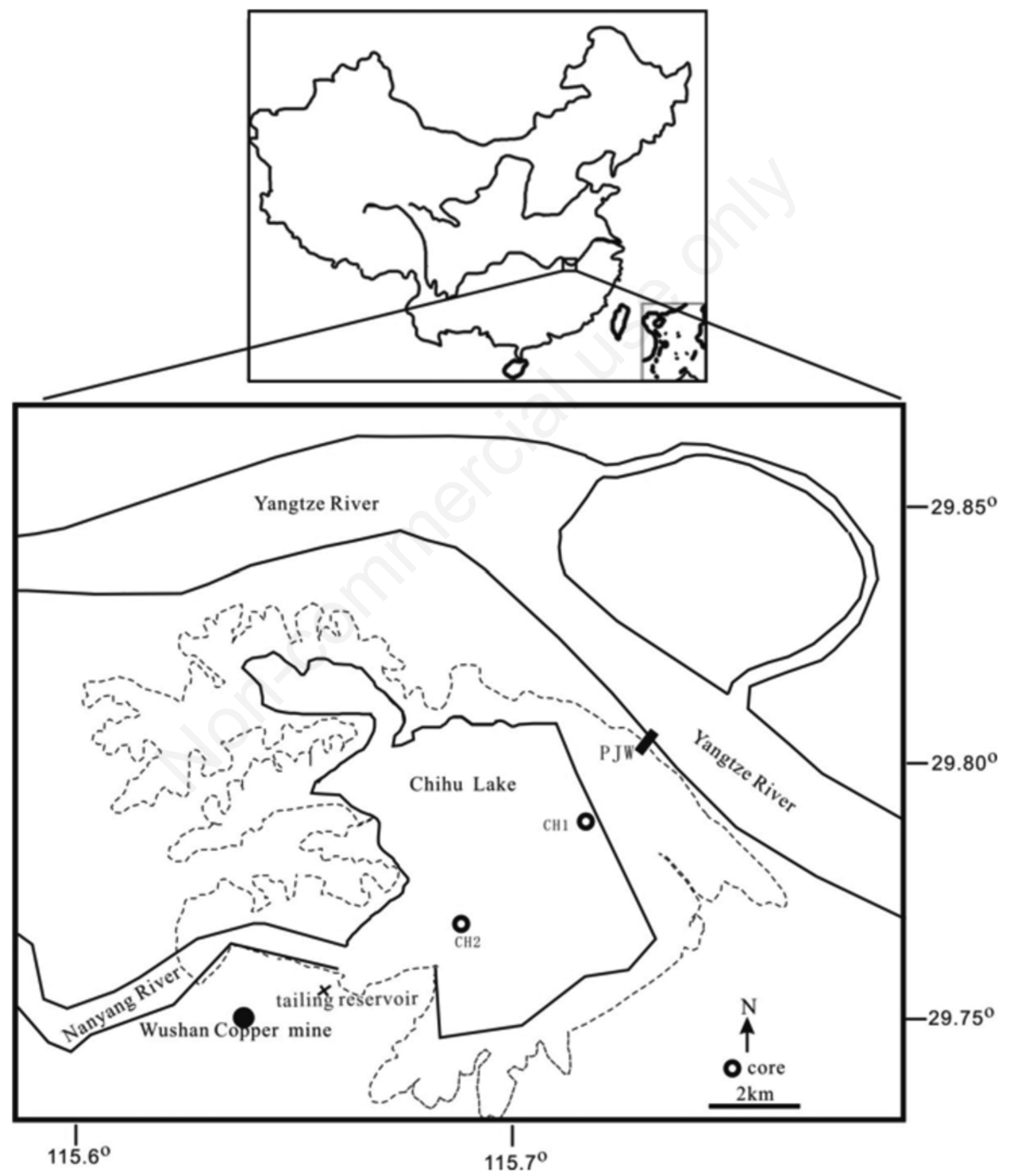

Fig. 1. Location of the study area showing Chihu Lake and the coring sites. The dotted line representing the lake area is modified from Wang and Dou (1998). 
Lake, respectively, using a gravity corer with a diameter of $5.9 \mathrm{~cm}$ (Fig. 1). The lengths of the two cores were 89 and $95 \mathrm{~cm}$, respectively. The core sediments were sectioned at $1.0 \mathrm{~cm}$ intervals. The slices were oven dried at $60^{\circ} \mathrm{C}$ for approximately $72 \mathrm{~h}$. The two cores were selected for radiometric dating using ${ }^{210} \mathrm{~Pb}$ and ${ }^{137} \mathrm{Cs}$.

${ }^{210} \mathrm{~Pb}$ and ${ }^{137} \mathrm{Cs}$ were determined using EG and $\mathrm{G}$ Ortec Gamma Spectrometry at the Nanjing Institute of Limnology and Geography of the Chinese Academy of Sciences. ${ }^{137} \mathrm{Cs}$ was measured at $662 \mathrm{keV}$, whereas ${ }^{210} \mathrm{~Pb}$ was determined via gamma emission at $46.5 \mathrm{keV}$. ${ }^{226} \mathrm{Ra}$ was detected in 295 and $352 \mathrm{keV} \gamma$-rays emitted by its daughter isotope ${ }^{214} \mathrm{~Pb}$ (Wan et al., 1987). The magnetic susceptibility was measured using a dual frequency Bartington Instruments MS2 sensor. The loss-on-ignition $\left(\mathrm{LOI}_{550}\right)$ procedure followed the protocol by Heiri et al. (2001). The dried and ground samples (approximately $0.125 \mathrm{~g}$ each) were digested with $\mathrm{HCl}-\mathrm{HNO}_{3}-\mathrm{HClO}_{4}$ in a Teflon beaker. Elements, including $\mathrm{Pb}, \mathrm{Cu}, \mathrm{Zn}, \mathrm{Cd}, \mathrm{Cr}, \mathrm{Co}, \mathrm{Ni}$ and $\mathrm{Mn}$, were measured using inductively coupled plasma mass spectroscopy (ICP-MS) (Agilent Technologies, Santa Clara, CA, USA, 7700x). Elements, including Al, $\mathrm{Fe}, \mathrm{K}, \mathrm{Mg}, \mathrm{Ti}$, Ca and total phosphorus (TP), were measured using ICP-AES (Leeman Labs, Hudson, NH, USA; Profile DV). The data quality was ensured using duplicates, blanks, and standard reference materials, such as GSD-18, which was supplied by the Chinese Academy of Geological Sciences. The recoveries of the metals varied, but all of the values were over the range of $92-105 \%$, and the relative standard deviation (RSD) was less than $8 \%$. Replicates were measured on each sediment sample. The isotopes ${ }^{206} \mathrm{~Pb},{ }^{207} \mathrm{~Pb}$ and ${ }^{208} \mathrm{~Pb}$ were measured using ICPMS. An international standard reference material (SRM981-NIST) was selected for calibration. The average measured ratio of ${ }^{206} \mathrm{~Pb} /{ }^{207} \mathrm{~Pb}$ of the external standard (GBW04426) was $1.1518 \pm 0.0008$ (for seven replicates). A good agreement was obtained between the measured lead isotope ratios and the certified values for GBW04426 (1.1525).

\section{RESULTS}

\section{Sediment chronology}

In the $\mathrm{CH} 1$ core, the first appearance of ${ }^{137} \mathrm{Cs}$ was recorded at $28.5 \mathrm{~cm}$ (Fig. 2), which can be dated to the early 1950 s, assuming that there was no vertical immigration of ${ }^{137} \mathrm{Cs}$ in the core. ${ }^{137} \mathrm{Cs}$ peaked at $20.5 \mathrm{~cm}$, which may be dated to 1963 and corresponds to a nuclear test in the early 1960 s, although there was another peak at a depth of $8.5 \mathrm{~cm}$. The later peak was not selected as the 1963 time marker because erosion could have subsequently brought deposited ${ }^{137} \mathrm{Cs}$ in the catchment into Chihu Lake. ${ }^{137} \mathrm{Cs}$ peaked at $20.5 \mathrm{~cm}$ in the $\mathrm{CH} 1 \mathrm{core}$, suggesting an average sediment rate of $0.42 \mathrm{~cm} \mathrm{a}^{-1}$.

Using the CIC (constant initial concentration) model of ${ }^{210} \mathrm{~Pb}$, the average sediment rate of $0.84 \mathrm{~cm} \mathrm{a}^{-1}$ can be calculated in the section in the $\mathrm{CH} 1$ core, which was quite different from ${ }^{137} \mathrm{Cs}$ result. ${ }^{210} \mathrm{~Pb} \mathrm{CRS}$ (constant rate of supply of ${ }^{210} \mathrm{~Pb}$ ) model and composite model from CRS are commonly used to date sediment ages of shallow lakes at Yangtze River Basin (Rose et al., 2004; Wu et al., 2008; Liu et al., 2012; Yao and Xue, 2015). The CRS model

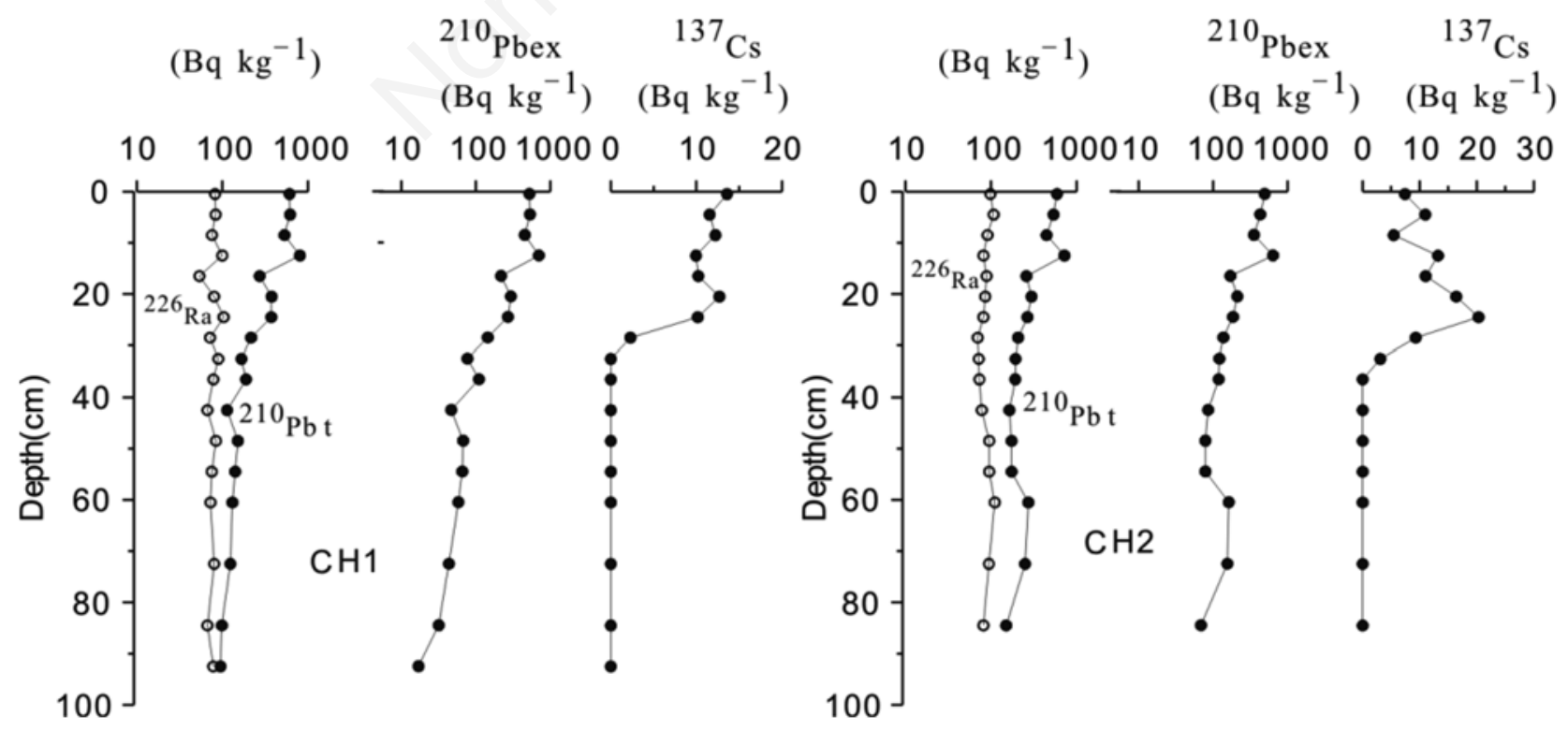

Fig. 2. Vertical profiles of ${ }^{226} \mathrm{Ra},{ }^{210} \mathrm{Pbt}$ (total ${ }^{210} \mathrm{~Pb}$ ), ${ }^{210} \mathrm{Pbex}$ and ${ }^{137} \mathrm{Cs}$ at Chihu Lake. 
gave an age of around 2000 at $20.5 \mathrm{~cm}$ depth where ${ }^{137} \mathrm{Cs}$ peaked revealing the discrepancy between the two methods. It can be found that at the bottom of the $\mathrm{CH} 1$ core, the ${ }^{210} \mathrm{~Pb}$ reached equilibrium with ${ }^{226} \mathrm{Ra}$, implying that the bottom of the core was approximately 130-150 years old. In this study we selected composite model of ${ }^{210} \mathrm{~Pb}$ to date $\mathrm{CH} 1$ core using the ${ }^{137} \mathrm{Cs}$ date as a reference point.

In the $\mathrm{CH} 2$ core, the first appearance of ${ }^{137} \mathrm{Cs}$ was recorded at $32.5 \mathrm{~cm}$, and ${ }^{137} \mathrm{Cs}$ then peaked at $24.5 \mathrm{~cm}$ (Fig. 2 ), corresponding to the early $1960 \mathrm{~s}$. The ${ }^{137} \mathrm{Cs}$ marker gave an average sediment rate of $0.51-0.56 \mathrm{~cm} \mathrm{a}^{-1}$. An average sediment rate of $0.71 \mathrm{~cm} \mathrm{a}^{-1}$ in the layers of $0-42.5 \mathrm{~cm}$ also can be obtained using the CIC model based on the relationship between the excess ${ }^{210} \mathrm{~Pb}$ and the sediment depth in the $\mathrm{CH} 2$ core. The inconsistency between the two independent methods suggested that the ${ }^{210} \mathrm{~Pb}$ CIC dating method was unsuitable for sediment layers of $0-42.5 \mathrm{~cm}$ at the $\mathrm{CH} 2$ site. For sediments below $54.5 \mathrm{~cm}$, the dates also cannot be obtained due to the very high activities of the excess ${ }^{210} \mathrm{~Pb}$ (Fig. 2). In this study, we established the sediment chronology of the upper $32.5 \mathrm{~cm}$ layers of the $\mathrm{CH} 2$ core from the ${ }^{137} \mathrm{Cs}$ distribution. For the lower parts of the core, the sediment age was used based on the comparison of the magnetic susceptibility, showing an excellent correlation between $\mathrm{CH} 1$ and $\mathrm{CH} 2$ with small differences in the depth of the two significant peaks (Fig. 3).

\section{$\mathrm{LOI}_{550}, \mathrm{Ca}$ and TP}

Generally, the two cores showed an increase in the $\mathrm{LOI}_{550}$ with decreasing depth, except for the top $10 \mathrm{~cm}$ layers of the CH1 core (Fig. 4). Very low values of the LOI occurred in certain layers between 40 and $65 \mathrm{~cm}$ of the $\mathrm{CH} 2$ core. The continuous increase in the $\mathrm{LOI}_{550}$ represents the increasing organic matter in the lake sediment, which is comparable to the pattern in the organic matter previ- ously reported for recent lacustrine sediments from the Yangtze River Basin (Xue et al., 2010; Zhang et al., 2010). The TP concentrations were relatively low at depths less than $60 \mathrm{~cm}$ in the two Chihu cores (Fig. 4). In the upper $60 \mathrm{~cm}$ sediments, the TP value remained relatively stable, although a small increase can be observed in the uppermost layers. The $\mathrm{Ca}$ concentrations were higher in the upper 25 sediments compared with those in the lower part in the $\mathrm{CH} 1$ core (Fig. 4). In the $\mathrm{CH} 2$ core, the Ca contents generally decreased from the bottom to approximately 30 $\mathrm{cm}$ then increased upward to $8.5 \mathrm{~cm}$ and, finally, showed a decrease to the surface sediment (Fig. 4).

\section{Changes in the metals and the ${ }^{206 / 207} \mathrm{~Pb}$ in the cores}

In the $\mathrm{CH} 1$ and $\mathrm{CH} 2$ cores, the $\mathrm{Fe}, \mathrm{Al}, \mathrm{K}, \mathrm{Mg}$ and $\mathrm{Ti}$ contents decreased from $30 \mathrm{~cm}$ to approximately $15 \mathrm{~cm}$

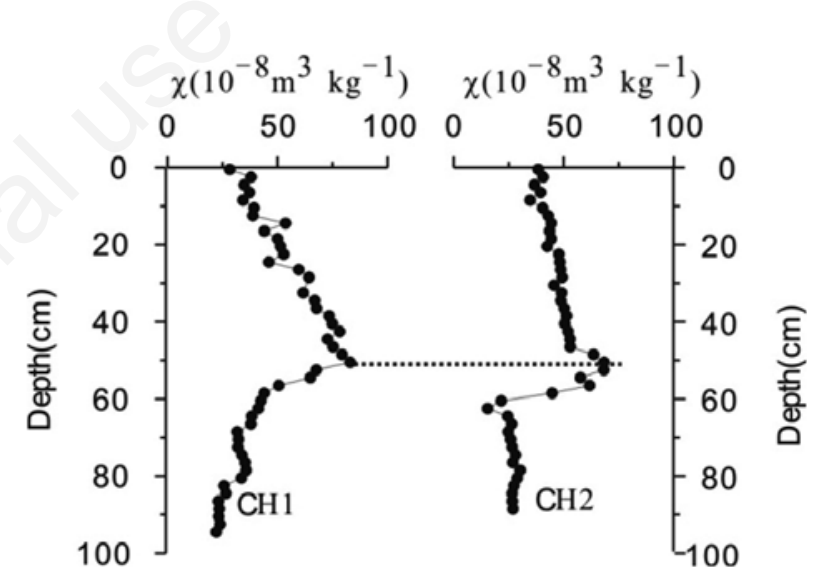

Fig. 3. Sediment magnetic susceptibility ( $\chi$ mass) of the $\mathrm{CH} 1$ core and the $\mathrm{CH} 2$ core.

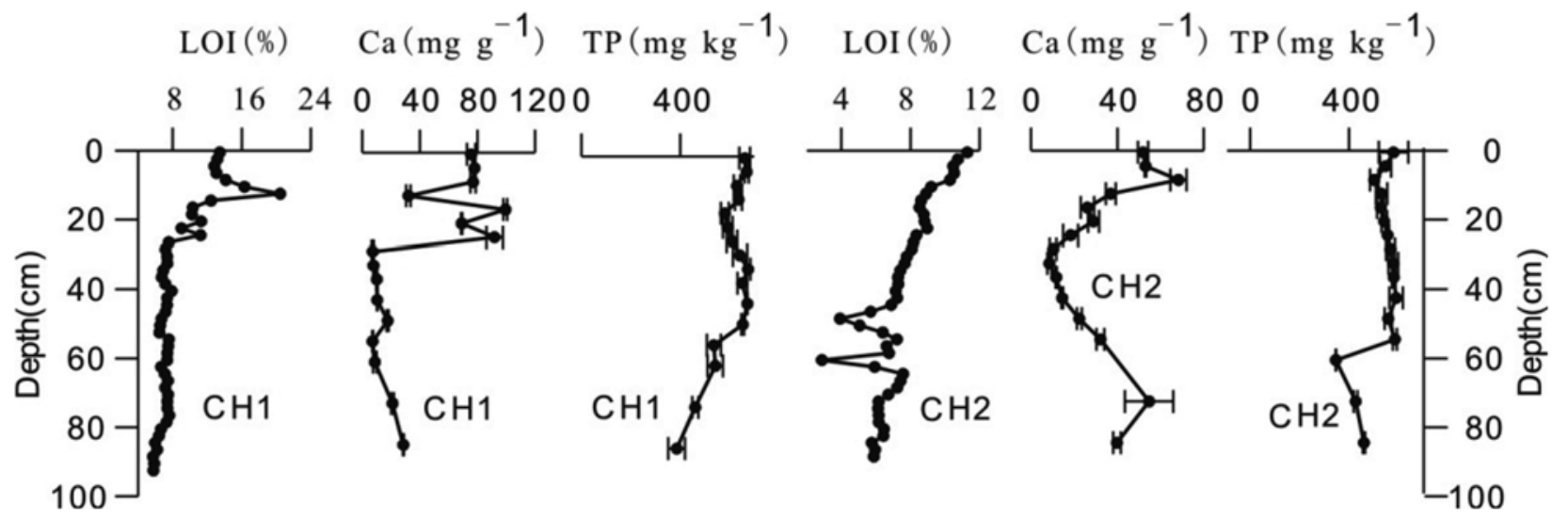

Fig. 4. Depth profiles of the LOI, Ca and TP in the cores from Chihu Lake. 
and then remained relatively stable (Fig. 5). Significant changes in the $\mathrm{Fe}, \mathrm{Al}, \mathrm{K}, \mathrm{Mg}$ and Ti contents can be observed between 40 and $65 \mathrm{~cm}$ in the $\mathrm{CH} 2$ core. $\mathrm{Fe}$ is diagenetic and mobile in many aquatic systems, depending on the redox conditions (Boyle et al., 1999). The small increase in the Fe content in the upper sediments and the synchronous changes with $\mathrm{Al}, \mathrm{K}$ and $\mathrm{Mg}$ indicated that this metal was not significantly influenced by the diagenetic remobilization process (Fe:Mn) within the Chihu sedimentary cores (Fig. 5).

Fig. 6 presents the heavy metal profiles for the Chihu Lake cores. Generally, $\mathrm{Pb}, \mathrm{Cu}, \mathrm{Zn}$, and $\mathrm{Cd}$ increased sharply from approximately $25 \mathrm{~cm}$ to $12.5 \mathrm{~cm}$ and then a slight decrease until $4.5 \mathrm{~cm}$. The maximum concentrations for $\mathrm{Pb}, \mathrm{Cu}, \mathrm{Zn}$ and $\mathrm{Cd}$ were $77.6,337,325$ and $9.31 \mathrm{mg}$ $\mathrm{kg}^{-1}$ dry mass, respectively in the $\mathrm{CH} 1$ core. $\mathrm{Cr}$, Co and Ni profiles paralleled those of $\mathrm{Fe}, \mathrm{Al}$, and $\mathrm{K}$ in the $\mathrm{CH} 1$ core (Figs. 5 and 6). The Mn concentration demonstrated a very high value in the $13-14 \mathrm{~cm}$ sediment in the $\mathrm{CH} 1$ core. The maximum concentrations for $\mathrm{Pb}, \mathrm{Cu}, \mathrm{Zn}$ and $\mathrm{Cd}$ were $174,2047,1343$ and $60.9 \mathrm{mg} \mathrm{kg}^{-1}$ dry mass, respectively, in the $\mathrm{CH} 2$ core. The $\mathrm{Mn}$ concentration increased sharply in the uppermost sediments in the $\mathrm{CH} 2$ core.

$\mathrm{The}{ }^{206} \mathrm{~Pb} /{ }^{207} \mathrm{~Pb}$ and ${ }^{208} \mathrm{~Pb} /{ }^{206} \mathrm{~Pb}$ ratios showed a significant decrease or increase $(\mathrm{P}<0.01)$ after the 1960s (at approximately $25 \mathrm{~cm}$ ) in the $\mathrm{CH} 2$ core (Fig. 7). At depths less than $15 \mathrm{~cm}$, the ${ }^{206} \mathrm{~Pb} /{ }^{207} \mathrm{~Pb}$ or ${ }^{208} \mathrm{~Pb} /{ }^{206} \mathrm{~Pb}$ ratios were relatively stable, and these ratios showed a linear relationship.

\section{PCA analysis}

After testing the suitability of the dataset for factor analysis, the multivariate technique of principal components analysis (PCA) varimax rotation was applied to the analyzed matrix of the metals, the LOI, TP and magnetic susceptibility of the Chihu sediments. Rotation of the factor solution is required for an improved interpretation. Two significant components were distinguished from the analyzed data. To interpret a group of variables to be associated with a particular factor, loadings greater than 0.6 were considered.

The first axis explains $58 \%$ of the total variance contribution in the $\mathrm{CH} 1$ core sediment, correlate positively with $\mathrm{Al}, \mathrm{Fe}, \mathrm{K}, \mathrm{Mg}$, Ti, $\mathrm{Cr}, \mathrm{Co}, \mathrm{Ni}$ and the magnetic susceptibility and negatively with $\mathrm{Ca}$ (Tab. 1). The first axis primarily reflected the detrital input from the catchment. The second axis, explains $33 \%$ of the common variance of the data set, is highly loaded with $\mathrm{Cu}, \mathrm{Cd}, \mathrm{Pb}, \mathrm{Zn}, \mathrm{Mn}$, LOI and TP (Tab. 1), which primarily represented the materials of anthropogenic influence. The results of the PCA analysis of $\mathrm{CH} 2$ were different from those of $\mathrm{CH} 1$ (Tab. 1). The first axis explains $46 \%$ of the total variance contribution in the $\mathrm{CH} 2$ core sediment, correlate positively with $\mathrm{Cu}, \mathrm{Cd}, \mathrm{Pb}, \mathrm{Zn}, \mathrm{Mn}, \mathrm{Co}, \mathrm{Ni}$ and LOI, whereas the second axis is positively loaded with $\mathrm{Al}, \mathrm{Fe}$, $\mathrm{K}, \mathrm{Mg}, \mathrm{Ti}, \mathrm{Cr}$, TP and the magnetic susceptibility, and negatively with $\mathrm{Ca}$ (Tab. 1).
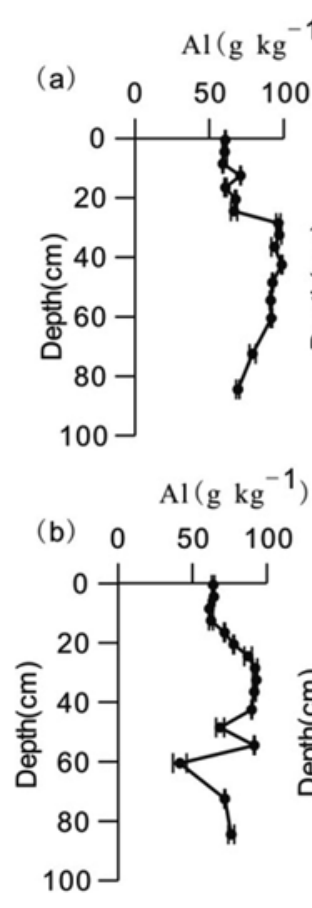
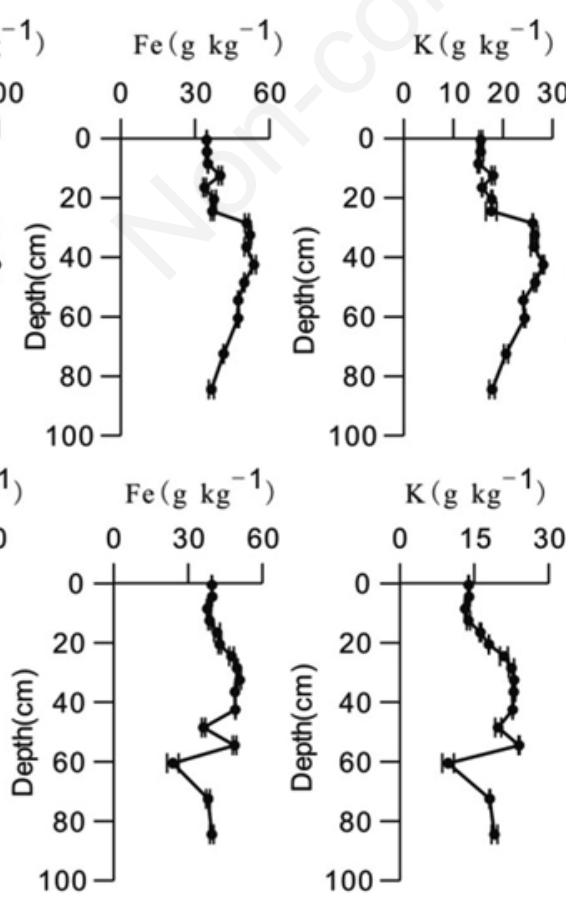
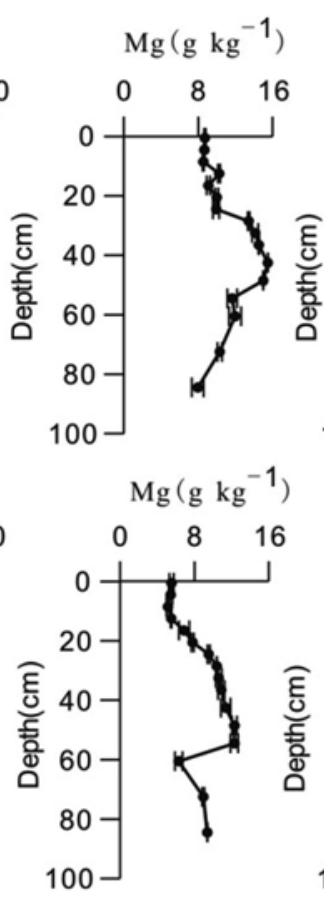

e: $\mathrm{Mn}$
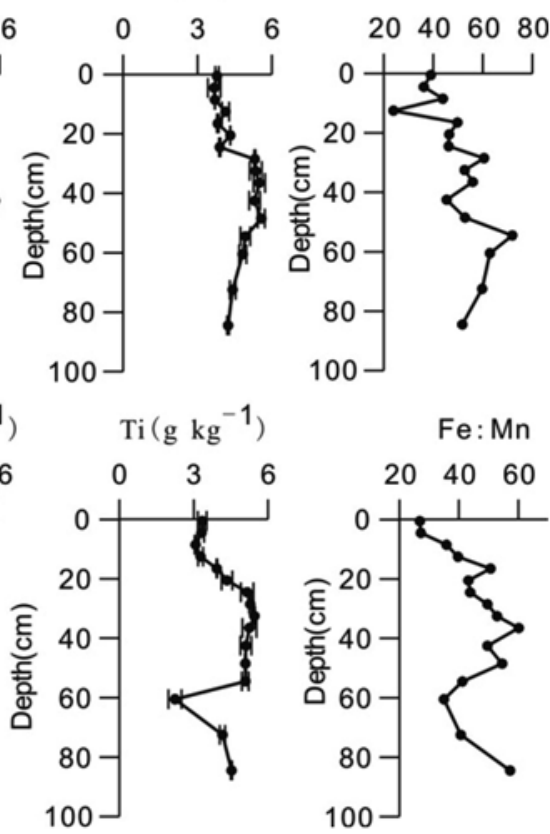

Fig. 5. Depth profiles of the major elements and Fe:Mn ratio in the cores from Chihu Lake. a) $\mathrm{CH} 1$ core. b) $\mathrm{CH} 2$ core. 


\section{Enrichment factors}

Enrichment factors (EF) are commonly used to point out the degree of heavy metal pollution in sediments by normalizing the elemental distributions to a conservative element, such as Al, Fe or Ti (Covelli and Fontolan, 1997).

These elements including Al, Fe and Ti are derived from the weathering of the parent materials in the local bedrock and reflect the natural variability in the sediments. Al, Fe and Ti have been widely used as tracer elements in heavy metal pollution studies. In this study, Al was used to generate the enrichment factors. If the lake sediments completely originated from the initial soil or bed-rock without an anthropogenic influence, then the EF value should be 1 . When the EF value is larger than 1, there should be another source in addition to a natural input, which can be attributed to an anthropogenic input. The contents of the metals in the lower section of the two
Chihu Lake cores (deposited before 1950s) were generally low and constant, indicating limited pollution due to a lower population, few industrial activities (such as mining and refining) in the catchment. Thus, the sediments prior to $1950 \mathrm{~s}$ were used as the background for the assessment of trace metals pollution in the present work.

The EF values of $\mathrm{Cr}$ showed nearly no fluctuation from the bottom to the surface, which indicated that the element in the lake sediments had little or no anthropogenic influence. The EF values of $\mathrm{Cd}, \mathrm{Cu}, \mathrm{Pb}$, and $\mathrm{Zn}$ retained the synchronous trends with their concentrations, which started to increase approximately during the 1960s (Fig. 8). This fact implies that these elements received more anthropogenic inputs after the 1960s in Chihu Lake than prior to that decade. The anthropogenic input of $\mathrm{Cd}$, $\mathrm{Cu}, \mathrm{Zn}$, and $\mathrm{Pb}$ increased rapidly to $13 \mathrm{~cm}$ and, afterwards, showed a small increase or remained stable.

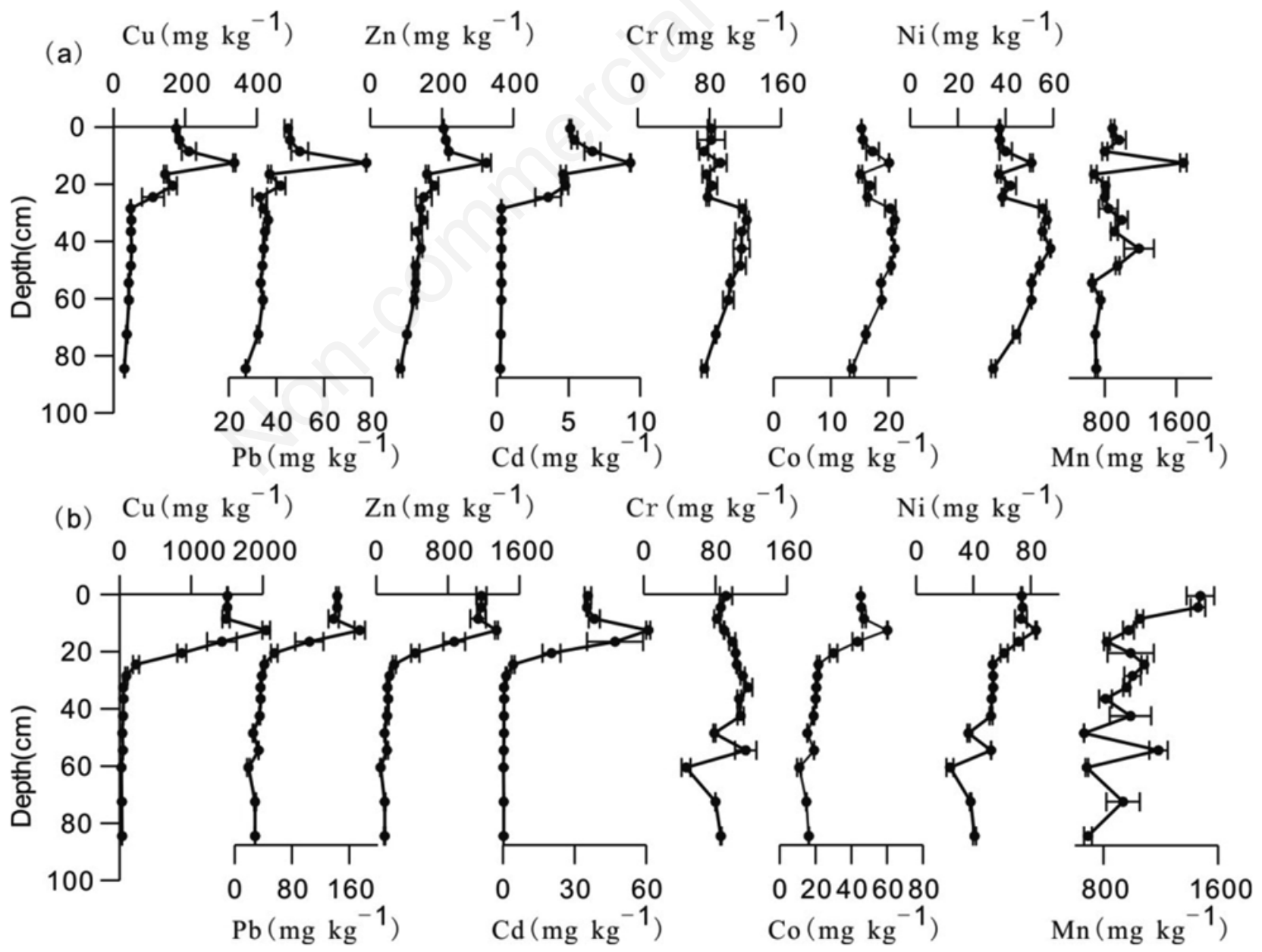

Fig. 6. Depth profiles of the heavy metals in the cores from Chihu Lake. a) $\mathrm{CH} 1$ core. b) $\mathrm{CH} 2$ core. 


\section{DISCUSSION}

\section{Metal mobility}

For heavy metals released from mining waste, the studied lake is a suitable sink because heavy metal records have demonstrated a succession, which most likely relates to different solubility and adsorption properties of the metal cations. These metals were released via the oxidation process and were transported with acid waters leaking from the mine area until they were buried in the Chihu Lake sediment by adsorbing to the organic matter or by precipitation process. The solubility of lead is less than that of copper and zinc (Adriano, 1986), which most likely explains the anthropogenic lead increase approximately 10 years later (Fig. 8).

Manganese enrichment in the surface sediments of the lakes around the world is common, which may cause metal redistribution (Boyle, 2001). In our study, the Mn contents in the surface sediments (the top $5 \mathrm{~cm}$ ) were significantly elevated in the $\mathrm{CH} 2$ core, and a very high $\mathrm{Mn}$ value occurred at $13 \mathrm{~cm}$ of the $\mathrm{CH} 1$ core (Fig. 6). The PCA revealed that the Mn changes are not controlled by debris input in the lake (Tab. 1). The source of Mn from mining activities can also be excluded because the Mn profiles were not parallel to $\mathrm{Cu}$ and $\mathrm{Cd}$, which were primarily from mining waste. Therefore, these extreme changes in $\mathrm{Mn}$ imply a reactive $\mathrm{Mn}$ redox chemistry. The $\mathrm{Mn}$ in the sediments is dissolved under reducing conditions, migrates upward and accumulates in the oxidized surface sediments. However, in this study, the Mn redox cycling did not appear to significantly influence the redis- tribution of the trace elements because these elements did not show very high concentrations in most of the layers in which Mn was enriched.

The changes in the heavy metal contents related to mining are reproduced among the two cores, suggesting that they exhibit a relatively conservative behavior in the Chihu Lake sediments. The rapid upcore increase in the $\mathrm{Cu}, \mathrm{Pb}, \mathrm{Zn}$ and $\mathrm{Cd}$ concentrations in the two cores indicates little reworking of these metals within the sediments. Therefore, once incorporated into the sediments, it is unlikely that these mining-related metals were significantly altered by post depositional processes in the Chihu Lake sediments.

\section{Evidence for anthropogenic heavy metal contamination}

The pre-mining heavy metal concentrations (e.g., $\mathrm{Cu}$, $\mathrm{Zn}$, and $\mathrm{Cd}$ ) were relatively stable and were similar to the historic concentrations reported from Poyang Lake in Jiangxi (Liu, 1990; Yuan et al., 2011). The recent sediment $\mathrm{Cu}, \mathrm{Cd}, \mathrm{Zn}$ and $\mathrm{Pb}$ concentrations in the Chihu Lake were more variable due to the effect of human activities, such as mining. The maximum sedimentary contents of the heavy metals related to copper mining were exceptionally high and above the standards for marine sediment and soils (GB18668-2002, GB15618-2008). The maximum concentration for $\mathrm{Zn}$ exceeds $1000 \mathrm{mg} \mathrm{kg}^{-1}$ dry mass (DM), $2000 \mathrm{mg} \mathrm{kg}^{-1} \mathrm{DM}$ for $\mathrm{Cu}$ and $60 \mathrm{mg} \mathrm{kg}^{-1} \mathrm{DM}$ for $\mathrm{Cd}$ (Fig. 6). These values are more than one or two orders of magnitude higher than the mean background levels for unpolluted lake sediments in the middle Yangtze River
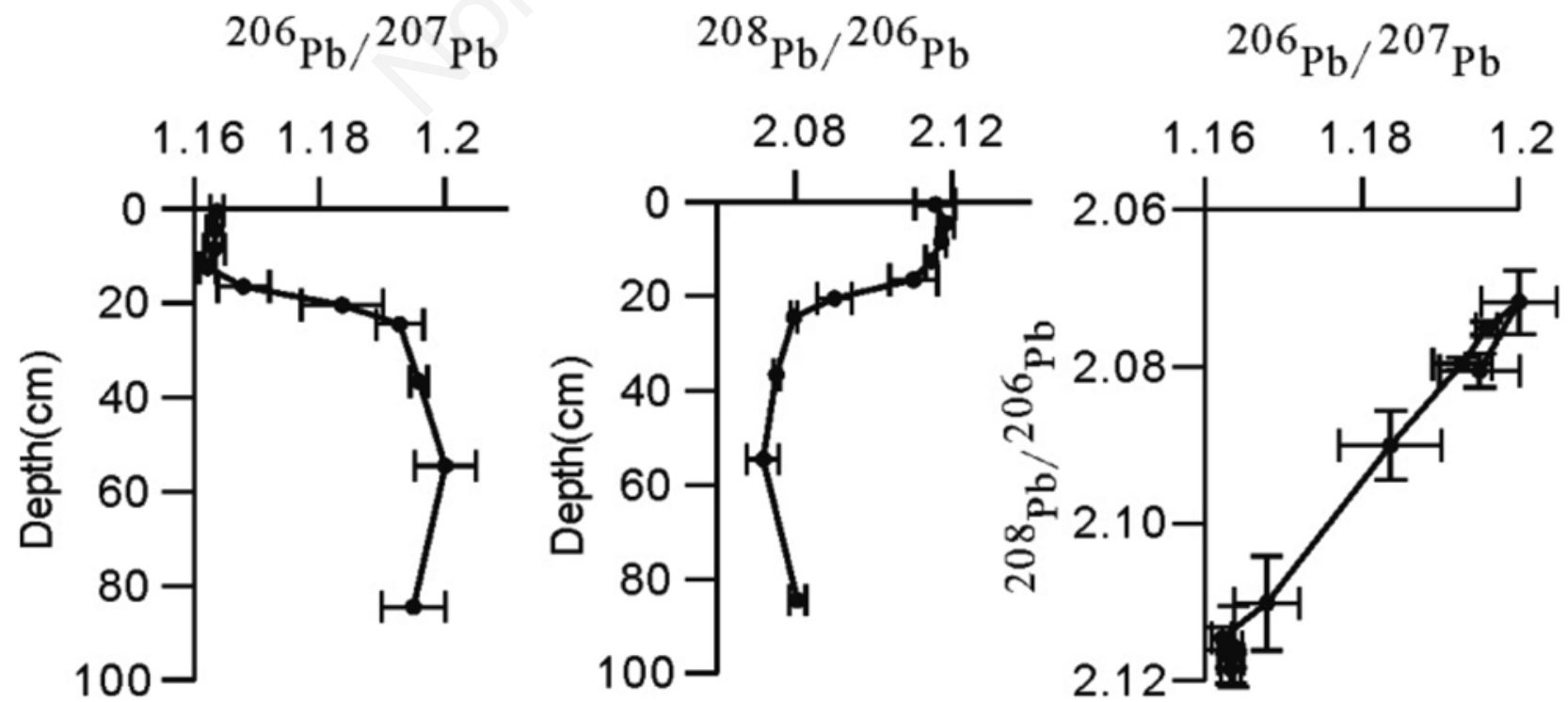

Fig. 7. Depth profiles of the $\mathrm{Pb}$ isotope ratios, ${ }^{206} \mathrm{~Pb} /{ }^{207} \mathrm{~Pb} v s^{208} \mathrm{~Pb} / 206 \mathrm{~Pb}$, at the $\mathrm{CH} 2$ core from Chihu Lake. 
drainage (Liu, 1990; Liu et al., 2007; Yuan et al., 2011; Wu et al., 2012; Bing et al., 2013). However, comparable high heavy metal contents have been found elsewhere, e.g., from Moshui Lake, receiving a high metal load due to the rapid urbanization and industrialization in Wuhan City (Liu et al., 2008). Chen et al. (2008) have also reported that the lead, zinc and copper concentrations in stream sediments exceeded 1\% DM, extending kilometers away from the mining activities.

Hilton et al.'s (1985) procedure can be used to detect the contribution of the anthropogenic heavy metal pollution. This procedure is performed by identifying a depth at which the heavy metal concentrations vary independently. At the Chihu Lake, such a depth can be simply identified for $\mathrm{Pb}, \mathrm{Cu}, \mathrm{Cd}, \mathrm{Zn}, \mathrm{Co}$ or $\mathrm{Ni}$, thus making it possible to determine the anthropogenic heavy metal contribution (Fig. 9). For Cr, the depth cannot be identified, thus making it difficult to determine the anthropogenic $\mathrm{Cr}$ contribution (Fig. 9). A lower anthropogenic contribution of $\mathrm{Cr}$ to the Chihu Lake sediments relative to the natural sources may explain the difficulty. In addition, high sediment rates further caused the low enrichment of $\mathrm{Cr}$ in the lake. Therefore, mining activities did not appear to significantly influence the $\mathrm{Cr}$ concentration.

Lead $(\mathrm{Pb})$ is a particularly well-known pollutant associated with mining and other human activities, such as vehicle transportation, coal combustion, lead ore exploitation and use, among others. Lead can be easily transported to aquatic systems by river or atmosphere. The ${ }^{206} \mathrm{~Pb} /{ }^{207} \mathrm{~Pb}$ ratios for the pre-mining Chihu sediments were approximately 1.20 . And the value of 1.20 for ${ }^{206} \mathrm{~Pb} /{ }^{207} \mathrm{~Pb}$ can be regarded as background value at Chihu Lake. The copper mining source of lead showed a ${ }^{206} \mathrm{~Pb} /{ }^{207} \mathrm{~Pb}$ value of 1.151-1.152 (Huang et al., 1990). Regional sources of lead also have a relatively low value of ${ }^{206} \mathrm{~Pb} / 207 \mathrm{~Pb}$ (Fig. 10). In the $\mathrm{CH} 2$ core of Chihu Lake, the ${ }^{206} \mathrm{~Pb} /{ }^{207} \mathrm{~Pb}$ ratios remained low or continued to decrease in recent sediments, indicating the increasing anthropogenic source of lead to the $\mathrm{CH} 2$ site over the past decades (Fig. 7).

\section{Sources of anthropogenic heavy metal}

The legacy of this $\mathrm{Cu}$ mining manifests itself within the local soils and the sediments of Chihu Lake. $\mathrm{Cu}, \mathrm{Pb}$, $\mathrm{Zn}$ and $\mathrm{Cd}$ anomalies in the local soils have been identified in the mining area (Liu et al., 1986) and have been linked to mining activities at the Wushan Copper Mine. The concentrations of $\mathrm{Cu}, \mathrm{Pb}, \mathrm{Zn}$ and $\mathrm{Cd}$ in the Chihu Lake sediments were significantly enriched, also reflecting the influence of the mining waste at the Wushan Copper Mine.

The mining effect may be limited in areas adjacent to the mine, or they can be transported off-site. There is a heavy metal $(\mathrm{Cu}, \mathrm{Pb}, \mathrm{Zn}$, and $\mathrm{Cd})$ decline with the distance from the source in the Chihu Lake sediment record.
The distance-decline effect is related to the mechanism by which the pollution metal is transferred to the sediment record. The sediments of the $\mathrm{CH} 2$ core, located near the Wushan Copper Mine, received large amounts of heavy metals from the drainage of the mine waste and a lesser amount of atmospheric deposition of heavy metals. The lead isotopic ratios and the metal contents revealed anthropogenic loading of the heavy metals into the lake after the 1960s, which corresponds to a period of Wushan Copper Mine exploitation and development.

In contrast to $\mathrm{Cu}$ or $\mathrm{Cd}$, which showed very high $\mathrm{EF}$ values, the enrichment factors of $\mathrm{Pb}$ in the topmost sedi-

Tab. 1. Factor loadings after the Varimax rotation (PC extracted 2 factors).

\begin{tabular}{lcccc} 
& \multicolumn{2}{c}{ CHi core } & \multicolumn{2}{c}{ CH2 core } \\
& Axis 1 & Axis 2 & Axis 1 & Axis 2 \\
$\mathrm{Al}$ & 0.94 & & & 0.94 \\
$\mathrm{Fe}$ & 0.98 & & 0.97 \\
\hline $\mathrm{K}$ & 0.95 & & 0.89 \\
$\mathrm{Mg}$ & 0.97 & & -0.72 & 0.65 \\
\hline $\mathrm{Ti}$ & 0.94 & & 0.86 \\
$\mathrm{Mn}$ & & 0.83 & & \\
\hline $\mathrm{Ca}$ & -0.81 & & & -0.93 \\
$\mathrm{TP}$ & & 0.62 & & 0.89 \\
\hline$\chi$ & 0.87 & & & 0.79 \\
$\mathrm{Zn}$ & & 0.97 & 0.97 & \\
\hline $\mathrm{Cr}$ & 0.98 & & & 0.96 \\
$\mathrm{Co}$ & 0.95 & & 0.98 & \\
\hline $\mathrm{Ni}$ & 0.99 & & 0.97 & \\
$\mathrm{Cu}$ & & 0.89 & 0.96 & \\
\hline $\mathrm{Cd}$ & 0.83 & 0.93 & \\
$\mathrm{~Pb}$ & & 0.95 & 0.97 & \\
\hline $\mathrm{LOI}$ & & 0.89 & 0.89 & \\
\hline
\end{tabular}

LOI, loss on ignition.

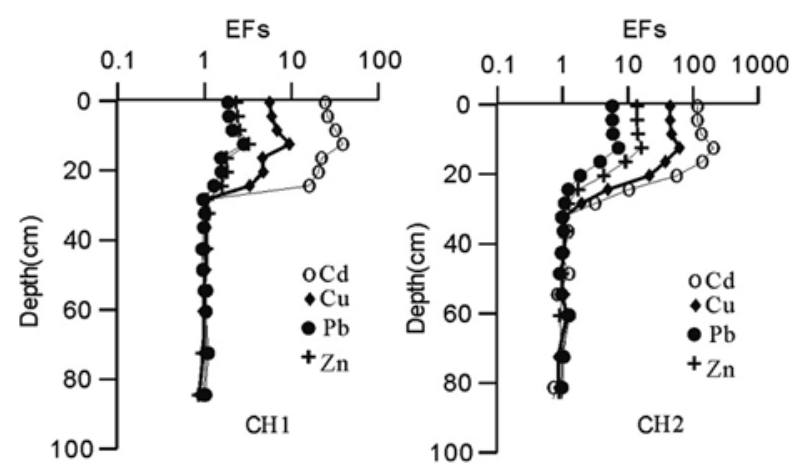

Fig. 8. Enrichment factors of the heavy metals at the Chihu Lake sediment cores. 
ments were approximately 7 and 2 in $\mathrm{CH} 2$ and $\mathrm{CH} 1$, respectively (Fig. 8). The extent of the $\mathrm{Pb}$ enrichment at the $\mathrm{CH} 1$ site was comparable to many lakes located in the middle and Yangtze River Basin in which there is no point pollution of $\mathrm{Pb}$ (Rose et al., 2004; Liu et al., 2007; Yao et al., 2009; Yuan et al., 2011). The low enrichment of $\mathrm{Pb}$ at $\mathrm{CH} 1$ implies that the atmospheric source of $\mathrm{Pb}$ loading to the lake cannot be ignored or may even be a major source to the lake sediment at the $\mathrm{CH} 1$ site.

To further investigate the possible sources of $\mathrm{Pb}$ in the sediments, the $\mathrm{Pb}$ isotopic compositions of the sediments were compared with the mining ores and other environmental samples (Fig. 10). The plot of the ${ }^{206} \mathrm{~Pb} /{ }^{207} \mathrm{~Pb}$ and ${ }^{208} \mathrm{~Pb} /{ }^{206} \mathrm{~Pb}$ ratios of the $\mathrm{CH} 2$ core sediments represents the $\mathrm{Pb}$ isotopic compositions during different historical periods. Prior to the $1960 \mathrm{~s}$, the ${ }^{206} \mathrm{~Pb} /{ }^{207} \mathrm{~Pb}$ ratios were at their highest, representing the background values during the pre-mining era (Fig. 10). Since the $1960 \mathrm{~s}$, the ${ }^{206} \mathrm{~Pb} / 207 \mathrm{~Pb}$ ratios have decreased, and have more closely resembled those of the mining materials (the Wushan copper) (Huang et al., 1990) and the regional sources of lead (Mukai et al., 2001; Zhang et al., 2006). The similar signature of the isotopic composition makes it difficult to quantitatively identify the local or regional sources of lead pollution of the Chihu Lake sediment. If the $\mathrm{CH} 1$ site primarily receives an atmospheric input of lead, then the mining waste source of $\mathrm{Pb}$ at $\mathrm{CH} 2$ was $0.001 \mathrm{~g} \mathrm{~cm}^{-2}$ estimated from the comparison of the anthropogenic flux of $\mathrm{Pb}$ in the two cores.

\section{Historical change in the anthropogenic heavy metals}

The similar heavy metal pollution signals identified within the two sediment cores of Chihu Lake allows them to be compared with the mining activities and the $\mathrm{Cu}$ production at the Wushan Copper Mine. Detailed records exist for the Wushan Copper Mine, including dates for the start of $\mathrm{Cu}$ mining, the population of the mine and for ore production (Compilation Committee of Chorography of Science and Technology of Wushan Copper, 1994; Li, 1999; Wu et al., 2001).

Mining began in 1970 in the Wushan Copper Mine area; however, the onset of changes in the sedimentary heavy metal profile was approximately during the early 1960 s in the two cores, which appears to predate the opening of the copper mining era. Although there is a level of uncertainty in the ${ }^{210} \mathrm{~Pb}$ dating and the bioturbation, resuspension, and diffusion that can distort the onset of changes in the sedimentary record, another explanation must be considered. The Wushan Copper Mine construction that started in 1966 can also enhance the metal (such as $\mathrm{Cu}$ ) loading into the Chihu Lake sediment. Population changes at the Wushan mine demonstrated a strong relationship with the $\mathrm{Cu}$ concentration after 1965 (Fig. 11), further confirming the above explanation. From 19781985, new techniques were introduced, leading to a rapid increase in the production and processing (Compilation Committee of Chorography of Science and Technology of Wushan Copper, 1994). In addition, the population in-

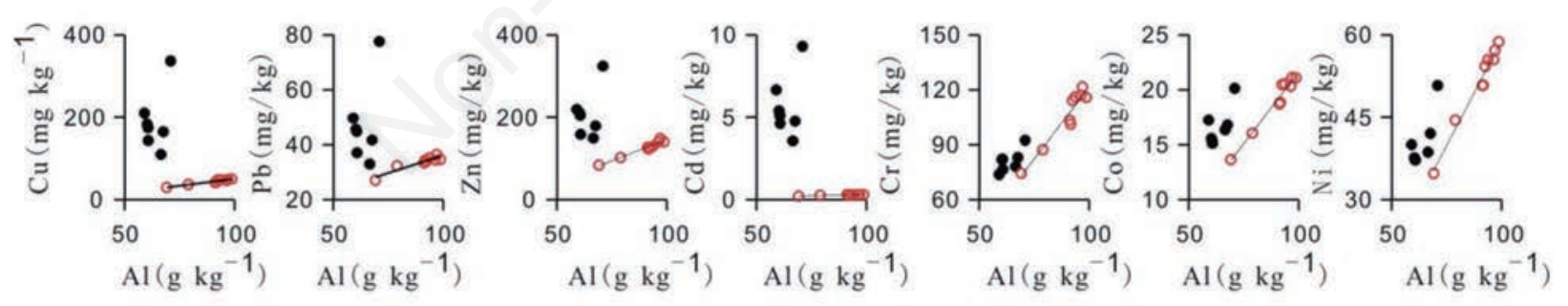

$\mathrm{CH} 1$

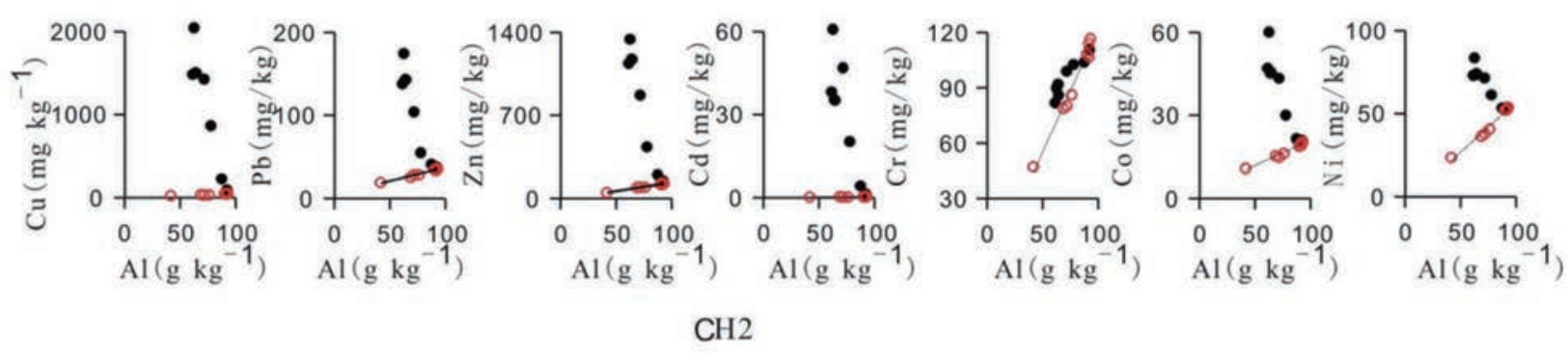

Fig. 9. Baseline estimates based on the procedure of Hilton et al. (1985). The filled squares represent samples that have a metal contribution from pollution. The open circles are those samples in the pre-mining period. 
creased rapidly during this time. Therefore, copper and other metals in the Wushan Lake sediments increased sharply during this period. However, after the mid-1980s, the $\mathrm{Cu}$ concentration did not parallel the ore production (Fig. 11). An analysis of the waste rock from the tailing reservoir revealed that after 1992, the $\mathrm{Cu}$ content decreased from $0.538 \%$ to $0.3 \%$ (Wang, 1997), which indicated the effect of the introduction of mining waste treatment in 1989.Additionally, most likely after 1989, the environmental protection, such as waste treatment, resulted in the reduced loading of the heavy metals from the mining waste to Chihu Lake.

\section{Influence of mining pollution on the lake plants}

The LOI began to increase after the 1950s in both of the cores. However, the magnitude of the increase of the LOI in $\mathrm{CH} 1$ was larger than that in $\mathrm{CH} 2$ (Fig. 12). There are two explanations for the difference in the two cores. First, more phosphorus inputs in the $\mathrm{CH} 1$ site caused more aquatic plants to grow; therefore, more organic matter was deposited compared with the $\mathrm{CH} 2$ site. Second, the abundance of aquatic plants was affected by the mining waste. The $\mathrm{CH} 2$ site was close to the Wushan copper mining area, whereas the $\mathrm{CH} 1$ site was relatively distant from the copper mine. The heavy metal analysis also revealed that the $\mathrm{CH} 2$ site was heavily polluted with a $\mathrm{Cu}$ concentration above $1000 \mathrm{mg} \mathrm{kg}^{-1}$ dry mass. The macrophyte surveys conducted in 1985 indicated the decrease of the aquatic plants in the lake area near the mine (Wu and $\mathrm{Wu}, 1996)$. In addition, human actives in the lake, such as crab farming, may be the reason for the LOI decline after the 1980s in the CH1 core.

The anthropogenic phosphorus was estimated from the TP normalized by Al for Chihu Lake sediments (Fig. 12)
(Wu et al., 2008; Liu et al., 2012). The increasing anthropogenic phosphorus inputs to Chihu Lake seems not to be related to the mining waste input because the phosphorus profiles did not parallel those of $\mathrm{Cu}, \mathrm{Zn}, \mathrm{Pb}$ and $\mathrm{Cd}$. In addition, anthropogenic phosphorus contents were lower in $\mathrm{CH} 2$ than those in $\mathrm{CH} 1$ (Fig. 12); the latter being the site closer to the mine pollution source. Re-

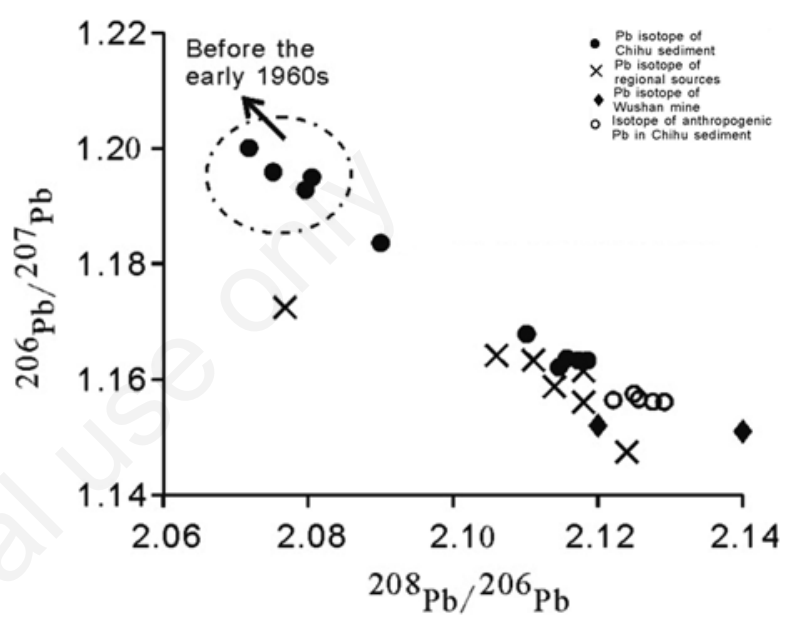

Fig. 10. The relationship between the ${ }^{206} \mathrm{~Pb} /{ }^{207} \mathrm{~Pb}$ and ${ }^{208} \mathrm{~Pb} /{ }^{207} \mathrm{~Pb}$ ratios of the sediments from Chihu Lake with other sources (ores, aerosols, coal dust, gasoline) from the middle and lower Yangtze region as reported in the literature (Mukai et al., 2001; Zhang et al., 2006). The anthropogenic $\mathrm{Pb}$ that accumulated in the $\mathrm{CH} 2$ core sediments of Chihu Lake was estimated from the enrichment factors (Shotyk et al., 2003; Yao et al., 2013).The isotopic compositions of the anthropogenic $\mathrm{Pb}$ were estimated using the mixing model following Bindler et al. (2001).
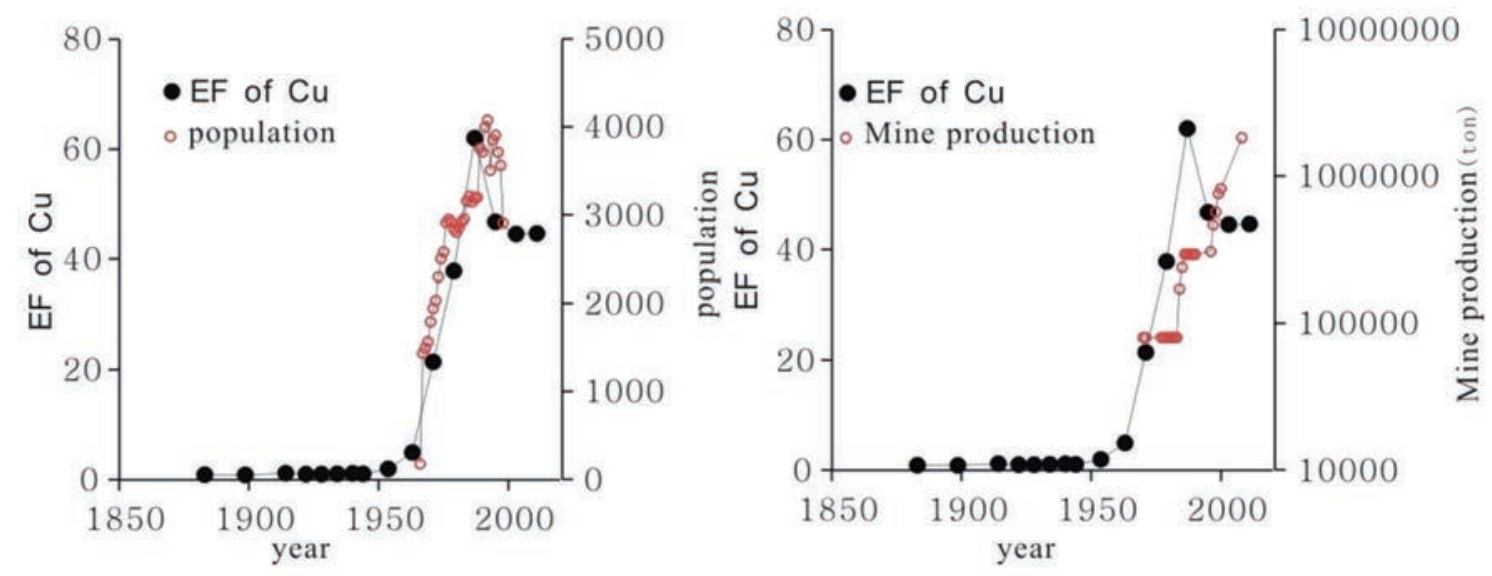

Fig. 11. Comparison of the enrichment factors of $\mathrm{Cu}$ in the $\mathrm{CH} 2$ core with the population at the Wushan Copper Mine (left) and with the mine production (right) (Wu et al., 2001). 
gional development, including farming activities and sewage input, can be the primary contribution to the rising phosphorus in the sediments over the past decades in Chihu Lake. Increases in the organic matter over the past decades should be primarily due to the increased growth of the aquatic plants rather than catchment input at $\mathrm{CH} 1$ site. Preservation was an important factor for the increasing organic matter deposition in $\mathrm{CH} 2$ site.

A survey conducted in 2007 showed that Chla was 3.6 $\mu \mathrm{g} \mathrm{L}{ }^{-1}$, and TP was $40 \mu \mathrm{g} \mathrm{L}^{-1}$. The water TP concentration was in the range of the background value of the Yangtze lakes (Yang et al., 2008; Chen et al., 2011). The increased nutrient input to Chihu Lake, caused macrophyte communities to flourish, and contribute the low TP concentration in the water. Brenner et al (1999) and Zhang et al. (2012) have found this phenomenon in macrophytes-dominated shallow lakes. The gradual loss of the macrophytes near the mining area, including the $\mathrm{CH} 1$ site, risked the transformation of macrophytes domination to algae domination.

\section{CONCLUSIONS}

The heavy metal content, the reference elements and the lead isotope ratios were used to detect the heavy metal pollution in the sediments from two cores extracted from Chihu Lake in the middle Yangtze River Basin in China. $\mathrm{The} \mathrm{Pb}, \mathrm{Cu}, \mathrm{Zn}, \mathrm{Cd}, \mathrm{Co}$ and $\mathrm{Ni}$ contents have increased over the past 30 to 40 years. The maximum concentration of $\mathrm{Cu}, \mathrm{Zn}$ and $\mathrm{Cd}$ recorded in the 1990s was 2047, 1343 and $60.9 \mathrm{mg} \mathrm{kg}^{-1}$, respectively. The heavy metal enrichment was high overall because of the mining waste discharge from the Wushan Copper Mine. The $\mathrm{Cu}$ concentrations in the sediment cores were not completely parallel to the copper ore production because the environmental protection measures, such as waste treatment, have resulted in the reduced loading of heavy metals from mining waste to Chihu Lake after the late 1980s.

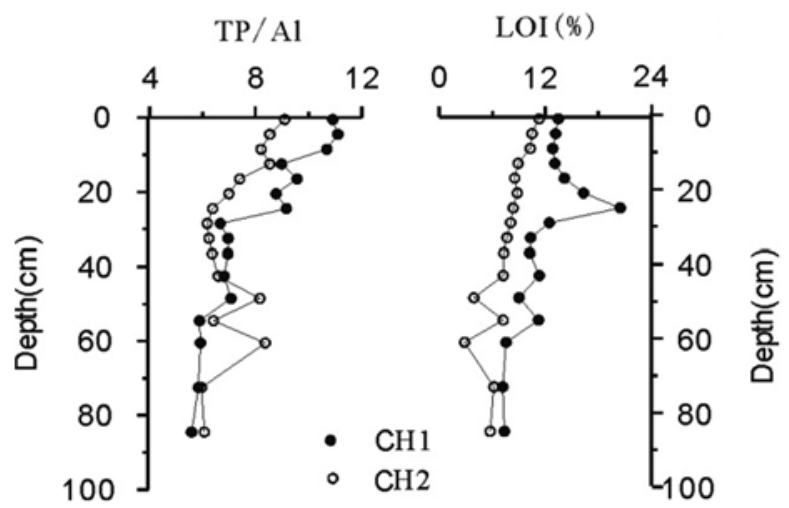

Fig. 12. Comparison of the Al-normalized TP and LOI in the $\mathrm{CH} 1$ and $\mathrm{CH} 2$ cores.

\section{ACKNOWLEDGMENTS}

The authors are very grateful to Dr. Wang Xiaocui and Dr. Li Shanyin for their support and help in the fieldwork. Gratitude should also be dedicated to Mr. Zhu Yuxing with the State Key Lab of Lake Science and Environment of the NIGLAS, Chinese Academy Science for his contribution to the analysis of the sediments. In addition, the authors are very grateful to the lake management committee of each lake for help in the fieldwork. This paper received support from a wide range of funding agencies including the Chinese National Science Foundation (41072133), 973 Project (2012CB956103) and Chinese Academy Science Strategic Priority Research Program (Grant No.XDA05120602).

\section{REFERENCES}

Adriano DC, 1986. Trace elements in the terrestrial environment. Springer: $867 \mathrm{pp}$.

Anomournas, 1977. [Test of Wushan Copper sewage treatment].[Article in Chinese]. Nonferrous Metals (Extractive Metallurgy): 27-32.

Arnason JG, Fletcher BA, 2003. A 40+ year record of Cd, Hg, $\mathrm{Pb}$, and $\mathrm{U}$ deposition in sediments of Patroon Reservoir, Albany County, NY, USA. Environ. Pollut. 123:383-391.

Audry S, Schafer J, Blanc G, Jouanneau JM, 2004. Fifty-year sedimentary record of heavy metal pollution $(\mathrm{Cd}, \mathrm{Zn}, \mathrm{Cu}$, $\mathrm{Pb}$ ) in the Lot River reservoirs (France). Environ. Pollut. 132:413-426.

Balogh SJ, Engstrom DR, Almendinger JE, Mcdermott C, Hu J, Nollet YH, Meyer ML, Johnson DK, 2009. A sediment record of trace metal loadings in the Upper Mississippi River. J. Paleolimnol. 41:623-639.

Bindler R, Renberg I, Anderson NJ, Appleby PG, Emteryd O, Boyle J, 2001. Pb isotope ratios of lake sediments in West Greenland: inferences on pollution sources. Atmos. Environ. 35:4675-4685.

Bing HJ, Wu YH, Nahm WH, Liu EF, 2013. Accumulation of heavy metals in the lacustrine sediment of Longgan Lake, middle reaches of Yangtze River, China. Environ. Earth Sci. 69:2679-2689.

Boyle JF. 2001. Inorganic geochemical methods in palaeolimnology, p. 83-141. In: W.M. Last and J.P. Smol (eds.), Tracking environmental change using lake sediments. 2. Physical and geochemical methods. Kluwer, Dordrecht.

Boyle JF, Rose NL, Bennion H, Yang H, Appleby PG, 1999. Environmental impacts in the Jianghan plain: Evidence from lake sediments. Water Air Soil. Poll. 112:21-40.

Brenner M, Whitmore TJ, Lasi MA, Cable JE, Cable PH, 1999. A multi-proxy trophic state reconstruction for shallow Orange Lake, Florida, USA: possible influence of macrophytes on limnetic nutrient concentrations. J. Paleolimnol. 21:215-233.

Chen CH, Ni SJ, He BB, Zhang CJ, 2008. [Spatial-temporal variation of heavy metals contamination in sediments of the dexing mine, Jiangxi province].[Article in Chinese]. Acta Geoscientica Sinica 29:639-646.

Chen X, Yang XD, Dong XH, Liu QA, 2011. Nutrient dynamics linked to hydrological condition and anthropogenic nutrient 
loading in Chaohu Lake (southeast China). Hydrobiologia 661:223-234.

Cheng HF, Hu YA, 2010. Lead (Pb) isotopic fingerprinting and its applications in lead pollution studies in China: a review. Environ. Pollut. 158:1134-1146.

Compilation Committee of Chorography of Ruichang County, 1990. [Chorography of Ruichang County].[Report in Chinese].

Compilation Committee of Chorography of Science and Technology of Wushan Copper, 1994. [Chorography of science and technology of Wushan copper]. Article in Chinese

Couillard Y, Cattaneo A, Gallon C, Courcelles M, 2008. Sources and chronology of fifteen elements in the sediments of lakes affected by metal deposition in a mining area. J. Paleolimnol. 40:97-114.

Covelli S, Fontolan G, 1997. Application of a normalization procedure in determining regional geochemical baselines. Environ. Geol. 30:34-45.

Ek AS, Renberg I, 2001. Heavy metal pollution and lake acidity changes caused by one thousand years of copper mining at Falun, central Sweden. J. Paleolimnol. 26:89-107.

Farmer JG, Mackenzie AB, Sugden CL, Edgar PJ, Eades LJ, 1997. A comparison of the historical lead pollution records in peat and freshwater lake sediments from central Scotland. Water Air Soil. Poll. 100:253-270.

Franco-Uria A, Lopez-Mateo C, Roca E, Fernandez-Marcos ML, 2009. Source identification of heavy metals in pastureland by multivariate analysis in NW Spain. J. Hazard. Mater. 165:1008-1015.

Grayson RP, Plater AJ, 2009. A lake sediment record of Pb mining from Ullswater, English Lake District, UK. J. Paleolimnol. 42:183-197.

Heiri O, Lotter AF, Lemcke G, 2001. Loss on ignition as a method for estimating organic and carbonate content in sediments: reproducibility and comparability of results. J. Paleolimnol. 25:101-110.

Hilton J, Davison W, Ochsenbein U, 1985. A MathematicalModel for Analysis of Sediment Core Data - Implications for Enrichment Factor Calculations and Trace-Metal Transport Mechanisms. Chem. Geol. 48:281-291.

Huang EB, Zhang NT, Luo ZS, 1990. [The genesis of the Chengmenshan and Wushan copper deposits].[Article in Chinese]. Mineral deposits 9:291-300.

Laperriere L, Fallu M-A, Hausmann S, Pienitz R, Muir D, 2008. Paleolimnological evidence of mining and demographic impacts on Lac Dauriat, Schefferville (subarctic Québec, Canada). J. Paleolimnol. 40:309-324.

Li H, 1999. [Statistical analysis and risk evaluation of annual casualties at Wushan Copper Mine].[Article in Chinese]. Jiangxi Nonferrous Metal 13:15-18.

Liu EF, Shen J, Birch GF, Yang XD, Wu YH, Xue B, 2012. Human-induced change in sedimentary trace metals and phosphorus in Chaohu Lake, China, over the past half-millennium. J. Paleolimnol. 47:1-15.

Liu EF, Yang XD, Shen J, Dong XH, Zhang EL, Wang SM, 2007. Environmental response to climate and human impact during the last 400 years in Taibai Lake catchment, middle reach of Yangtze River, China. Sci. Total Environ. 385:196-207.

Liu HL, Li LQ, Yin CQ, Shan BQ, 2008. Fraction distribution and risk assessment of heavy metals in sediments of Moshui Lake. J. Environ. Sci (China) 20:390-397.
Liu M, 1990. Heavy metal pollution at Poyang Lake. Enviromental Science and Technology 48:1-5 (in Chinese).

Liu YH, Zhao ZJ, Zeng YY, Zhang NZ, 1986. [An appraisal about the effects of the opening of Wushan Copper mine to the local soils and crops].[Article in Chinese]. Acta Agricultural Universities Jiangxiensis 8:75-82.

Marcantonio F, Zimmerman A, Xu YF, Canuel E, 2002. A Pb isotope record of mid-Atlantic US atmospheric $\mathrm{Pb}$ emissions in Chesapeake Bay sediments. Mar. Chem. 77:123-132.

Michelutti N, Laing TE, Smol JP, 2001. Diatom assessment of past environmental changes in lakes located near the Noril'sk (Siberia) smelters. Water Air Soil. Poll. 125:231-241.

Mukai H, Tanaka A, Fujii T, Zeng YQ, Hong YT, Tang J, Guo S, Xue HS, Sun ZL, Zhou JT, Xue DM, Zhao J, Zhai GH, Gu JL, Zhai PY, 2001. Regional characteristics of sulfur and lead isotope ratios in the atmosphere at several Chinese urban sites. Environ. Sci. Technol. 35:1064-1071.

Nriagu JO, 1998. Tales told in lead. Science 281:1622-1623.

Ostrofsky ML, Schworm AE, 2011. A history of acid mine contamination, recovery, and eutrophication in Sandy Lake, Pennsylvania. J. Paleolimnol. 46:229-242.

Pacyna JM, Pacyna EG, 2001. An assessment of global and regional emissions of trace metals to the atmosphere from anthropogenic sources worldwide. Environ. Rev. 9:269-298.

Rose NL, Boyle JF, Du Y, Yi C, Dai X, Appleby PG, Bennion H, Cai S, Yu L, 2004. Sedimentary evidence for changes in the pollution status of Taihu in the Jiangsu region of eastern China. J. Paleolimnol. 32:41-51.

Salonen VP, Tuovinen N, Valpola S, 2006. History of mine drainage impact on Lake Orijarvi algal communities, SW Finland. J. Paleolimnol. 35:289-303.

Shotyk W, Goodsite ME, Roos-Barraclough F, Frei R, Heinemeier J, Asmund G, Lohse C, Hansen TS, 2003. [Anthropogenic contributions to atmospheric $\mathrm{Hg}, \mathrm{Pb}$ and $\mathrm{As}$ accumulation recorded by peat cores from southern Greenland and Denmark dated using the $14 \mathrm{C}$ "bomb pulse curve"].[Article in Chinese]. Geochim. Cosmochim. Ac. 67:3991-4011.

Wan GJ, Santschi PH, Sturm M, Farrenkothen K, Lueck A, Werth E, Schuler C, 1987. Natural (Pb-210, Be-7) and Fallout (Cs-137, Pu-239-240, Sr-90) Radionuclides as Geochemical Tracers of Sedimentation in Greifensee, Switzerland. Chem. Geol. 63:181-196.

Wang LM, 1997. [Analysis of tailings recovery from Wushan Copper plant].[Article in Chinese]. Nonferrous Metallurgy Design and Research 18:38-52.

Wang SM, Dou HS, 1998. [Chinese Lake Annals].[Book in Chinese]. Science Press: 265 pp.

Wu HY, Zhang JC, Yu J, 2001. [Potential from the analysis of the production and operation during 9th Five-Year at Wushan Copper Mine].[Article in Chinese]. China Metal Bulletin 18-21.

Wu JL, Zeng HA, Yu H, Ma L, Xu LS, Qin BQ, 2012. Water and sediment quality in lakes along the middle and lower reaches of the Yangtze River, China. Water Resour. Manag. 26:3601-3618.

Wu WP, 1987a. [Preliminary investigation on the Chihu Lake aquatic vascular plants in Jiangxi Province].[Article in Chinese]. Journal of Jiangxi University (Natural Science) 11:64-71. 
Wu WP, 1987b. [The vegetation of Wushan Copper Mine field in Jiangxi and environmental protection].[Article in Chinese]. Journal of Jiangxi University (Natural Science) 11:54-61.

Wu WP, Wu ZZ, 1996. [The aquatic vascular plants of Chihu Lake of Jiangxi Province and their environmental impact].[Article in Chinese]. Journal of Nanchang University (Natural Science) 20:188-192.

Wu YH, Liu EF, Yao SC, Zhu YX, Xia WL, 2010. Recent heavy metal accumulation in Dongjiu and Xijiu lakes, East China. J. Paleolimnol. 43:385-392.

Wu YH, Lucke A, Wang SM, 2008. Assessment of nutrient sources and paleoproductivity during the past century in Longgan Lake, middle reaches of the Yangtze River, China. J. Paleolimnol. 39:451-462.

Xue B, Yao SC, Xia WL, Zhu YX, 2010. Some sediment-geochemical evidence for the recent environmental changes of the lakes from the middle and lower Yangtze River basin, China. Quatern. Int. 226:29-37.

Yang XD, Anderson NJ, Dong XH, Shen J, 2008. Surface sediment diatom assemblages and epilimnetic total phosphorus in large, shallow lakes of the Yangtze floodplain: their relationships and implications for assessing long-term eutrophication. Freshwater Biol. 53:1273-1290.

Yang HD, Rose N, 2005. Trace element pollution records in some UK lake sediments, their history, influence factors and regional differences. Environ. Int. 31:63-75.

Yao SC Xue B, 2015. Sedimentary geochemical record of human-induced environmental changes in Huanggaihu Lake in the middle reach of the Yangtze River, China. J. Limnol. 74:31-39.

Yao SC, Xue B, Tao YQ, 2013. Sedimentary lead pollution history: lead isotope ratios and conservative elements at East Taihu Lake, Yangtze Delta, China. Quatern. Int. 304:5-12.

Yao SC, Xue B, Xia WL, Zhu YX, Li SJ, 2009. Lead pollution recorded in sediments of three lakes located at the middle and lower Yangtze River basin, China. Quatern. Int. 208:145-150.

Yuan GL, Liu C, Chen L, Yang ZF, 2011. Inputting history of heavy metals into the inland lake recorded in sediment profiles: Poyang Lake in China. J. Hazard. Mater. 185:336-345.

Zhang EL, Cao YM, Langdon P, Jones R, Yang XD, Shen J, 2012. Alternate trajectories in historic trophic change from two lakes in the same catchment, Huayang Basin, middle reach of Yangtze River, China. J. Paleolimnol. 48:367-381.

Zhang EL, Liu EF, Jones R, Langdon P, Yang XD, Shen J, 2010. A 150-year record of recent changes in human activity and eutrophication of Lake Wushan from the middle reach of the Yangze River, China. J. Limnol. 69:235-241.

Zhang GL, Tan MG, Li XL, Zhang YX, Yue WS, Chen JM, Wang YS, Li AG, Li Y, Zhang YM, Shan ZC, 2006. [Comprehensive study of lead pollution in atmospheric aerosol of Shanghai].[Article in Chinese]. Environ. Sci. 27:831-836.

Zhao JX, 1994. [Wushan copper mine waste water treatment and comprehensive utilization].[Article in Chinese]. Journal of Kuming Institute of Technology 19:125-130. 